\title{
Contents, Vol. 16, 1977
}

Editor-in-Chief:

H.E. Kaeser, Basel

Associate Editors:

Ingrid Gamstorp, Uppsala

H.-G. Mertens, Wiirzburg

H. vander Eecken, Ghen

U.K. Rinne, Turku

Editorial Board:

L. Barraquer Bordas, Barcelona

S. Feldman, Jerusalem

S. Refsum, Oslo

W.G. Bradley,

P. Huber, Bern

E. Satoyoshi, Tokyo

A. Kreindler, Bucharest

A. Kreindler, Buchare

J. Droogleever Fortuyn

H.J. Lehmann, Essen

F. Vassella, Bern

Groningen

Proningen
Passouant, Montpellier

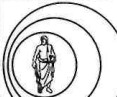

S.Karger • Basel • Munchen -Paris-London • New York• Sydney

Copyright 1977 by S. Karger AG
4011 Basel (Switzerland)

Arnold-Bocklin-Strasse 25

Printed in Switzerland by Thiir AG Offsetdruck

Pratteln 
All rights reserved.

No part of this publication may be translated into other languages, reproduced or utilized in any form or by any means, electronic or mechanical, including photocopying, recording, microcopying, or by any information storage and retrieval system, without permission in writing from the publisher.

\section{Contents}

Vuia, 0.: Morphologic Aspects of the Neurofi

brosarcoma (Neurogenic Sarcoma)

Guiang, R.L., jr. and Ellington, O.B.: Acute Pure

fartion 11

.

Lenzi, G.L. and Fieschi, C: Superior Orbital Fissure Syndrome. Review of 130 Cases ... 23

Vassilopoulos, D., Lumb, E.M., and Emery,

Muscle with Age 31

Negri, S.; Caraceni, T., and Boiardi, A.: Neuro-

myotonia. Report of a Case 35

Caraceni, T.; Giovannini, P.; Girotti, F., and

Avanzini, G.: Pharmacology of Huntington's

Chorea. Personal Experience 42

Askenasy, J.J.; Streifler, M., and Carasso, R.:

Moderate Nonketotic Hyperglycemia - a

Cause of Focal Epilepsy. Report of Two Cases

and Review of Literature 51

Szegedy, L. and Jongkind, J.F.: Glycolytic Sub
strate Utilization and Energy Consumption in

the Cerebral Hemispheres of the Mouse during

Experimental Anuria 62

Chan, K. and Calvey, T.N.: Renal Clearance of

Pyridostigmine in Patients with Myasthenia

gravis 69

Marttila, R.J. and Rinne, U.K.: Level of Blood

Pressure in Patients with Parkinson's Disease.

A Case-Control Study 73

Kjellin, K.G. and Siden, A.: Electrofocusing and

Electrophoresis of Cerebrospinal Fluid Pro

teins in CNS Disorders of Known or Probable

Infectious Etiology 79 
Kazakov, V.M.; Kovalenko, T.M.; Skorometz, A.A., and Mikhailov, E.P. Chronic Spinal Muscular Atrophy Simulating Facioscapulohumeral Type and Limb-Girdle Type of Muscular Dystrophy. Report of Two Cases .... 90 Capitani, E.; Meola, G., and Spinnler, H.: Amyo

trophy and Kluever-Bucy Syndrome. A Case

Report 99

Abbruzzese, M.; Loeb, C; Ratto, S., and Sacco, G.: A Comparative Electrophysiological and Histological Study of Sensory Conduction Velocity and Meissner Corpuscles of the Median Nerve in Pneumatic Tool Workers . . 106

Vignaendra, V.; Beng Hock Chong; Thiam Ghee

Loh, and Ah Hoo Ang: Occlusive Cerebrovas

cular Disease in Young Adults 115

Distinctive Features of Unilateral Spatial

Distinctive Features of Unilateral Spatial
Agnosia in Right and Left Brain-Damaged

Patients 121

Kuriyama, M.; İshii, N.; Umezaki, H., and Kano, M.: Polycythemia vera and Transient Monocular Blindness. Observation of the Platelet Embolic Phenomena in the Ocular Fundus . 127

Kitahara, T.; Shirai, S.; Owada, T., and Maki, Y.

Traumatic Middle Meningeal Arteriovenous

Cases 136

Fortuna, A. and La Torre, E.: The Lumbar Root

Entrapment Syndrome with Emphasis on

Clinical and Myelographic Findings 144

Sarova-Pinhas, I.; Siegal, T.; Turgman, J.,

matomyositis 149

Ionasescu, V.; Ionasescu, R.; Cancilla, P.; Kahn, L., and Zellweger, H.: Protein Synthesis in 
Contents

Muscle Cultures from Patients with Myotonic Dystrophy. Influence of A23187 Ionophore and Calcium: Preliminary Investigation

Shinohara, Y.; Yamaguchi, F., and Gotoh, F.:

Toxic Neuropathy as a Complication of

Thiophenicol Therapy

Ciganek, L.; Glivjak, F.; Rusnak, J., and Popper

M.: Computer-Assisted Recording of the $\mathrm{O}$

jective Neurologic Finding 165

Salisachs, P. and Lapresle, J.: Argyll-Robertson-

Like Pupils in the Neural Type of Charcot-

Marie-Tooth Disease

172

Caspary, E.A.: Effect of Live Attenuated Vac

cines on the Course of Experimental Allergic

Encephalomyelitis. A Pilot Study 176

Probst, A.; Ulrich, J.; Kaeser, H.E., and Heitz,

Ph.: Scapulo-Peroneal Muscular Atrophy. Ful

Autopsy Report. Unusual Findings in the

Anterior Horn of the Spinal Cord. Lipid

Storage in Muscle 181

Dumermuth, G., Gasser, T.; Germann, P.; Hecker,

A.; Herdan, M., and Lange, B.: Studies on

EEG Activities in the Beta Band

Strecker, E.-P.; Novak, G.R., and James, A.E., jr.

Compartmental Analysis of Cerebrospinal

cid-Blood Albumin Transfer: Considera

tion of Kin tics in Nomal Animals and Ani

mals with Chronic Communicating Hydro

Holbach, K.-H.; Wassmann, H., and Linke, D.

The Use of Hyperbaric Oxygenation in the 
Scarlato, G.; Albizzati, M.G.; Bassi, S.; Cerri, C, and Frattola, L. A Case of Lipid Storage Myopathy with Carnitine Deficiency. Biochemical and Electromyographic Correlations 222

Botez, M.I.; Fontaine, F.; Botez, T, and Bache-valier, J. Folate-Responsive Neurological and Mental Disorders: Report of 16 Cases. Neuropsychological Correlates of Computerized Transaxial Tomography and Radionuclide

Cisternography in Folic Acid Deficiencies ...230

Nilsson, O. and Thelin, C: Cellular Immunity to Encephalitogenic Protein in Multiple Sclerosis. Correlations with Other Laboratory Characteristics at Different Disease Courses . 247

Cendrowski, W. and Sobczyk, W: Clonazepam,

Baclofen and Placebo in the Treatment of

Lewit, K.: Pain Arising in the Posterior Arch of

the Atlas 263

Tackmann, W. and Minkenberg, R.: Nerve Con

duction Velocity of Small Components in

Human Sensory Nerves. Studies in Norma

and Diseased Nerves 270

Livrea, P.; Di Reda, L.; Puca, F.M.; Genco, S.;

Specchio, L.M., and Papagno, G.: Homovanil-

lic Acid and 5-Hydroxyindoleacetic Acid in

Lumbar Cerebrospinal Fluid after Total and

REM Sleep Deprivation in Humans 280

Emser, W. and Schimrigk, K.: Myxedema Myo

pathy: a Case Report 286

Author Index 293

Subject Index $\quad 294$ 